\title{
Development of a device for the reintegration of people with incomplete quadriplegia
}

\author{
Ana Luisa Oliveira da Nóbrega Costa ${ }^{a}$ (D), Tiago Camargo Alves $^{a}$ (D), Hugo Faria Frota ${ }^{(D)}$, Abner Pereira Duarte Silva ${ }^{a}$ \\ Miguel Alves Pereira Júnior ${ }^{a}\left(\mathbb{D}\right.$, Rafaela de Faria Dantas ${ }^{a}$ (D) , Emerson Fachin Martins ${ }^{b} \mathbb{D}^{D}$, Andrea Cristina dos Santos ${ }^{a}$ \\ - Faculdade de Tecnologia, Universidade de Brasilia - UNB, Brasilia, Distrito Federal, Brasil \\ b Faculdade de Ceilândia, Universidade de Brasilia - UNB, Braślia, Distrito Federal, Brasil \\ e-mails: analuisaonc@gmail.com; tiago.camargoalves@gmail.com; hugofrota@gmail.com; andreakieck@gmail.com; emersonntaai@gmail.com; \\ abner.pereira23@gmail.com; miguelir.prod@gmail.com; rafaela1996dantas@gmail.com;
}

\begin{abstract}
The product development process (PDP) presents interactive stages to be followed for the release of a product. The study adapts the classic PDP approach to a Project-Based Learning context guide the application for the development of an assistive device that allows people with incomplete quadriplegia to practice paralympic tennis with higher performance and comfort. The study was based on research performed within a nonprofit social assistance Association dealing with disabled people. The research identified that the main barrier faced by players of paralympic tennis is the difficulty to hold, maintain, and transmit power through the racket during the game. Based on this demand, the early stages of PDP were applied in a university PBL and the development of the new solution achieved Technological Readiness Level (TRL) of 2. The final deliverables were CAD model and a conceptual prototype.
\end{abstract}

Keywords: product development process, assistive technology, paralympic tennis, project-based learning.

\section{Introduction}

Wheelchair tennis is an adapted sport modality founded 1976 and is considered one of the most popular sports practiced by wheelchair users. From 1992 to 2016, the International Tennis Federation's Wheelchair Tennis Tour increased from 11 to 160 international events (Alden \& Aran, 2016). However, injuries affecting neuromusculoskeletal and movement of the upper limbs of the players during tennis practice are commonly reported, in which $20 \%$ occur in the hand, followed by shoulders (15.5\%), fingers (11.1\%), and arms (10\%). According to Caldwell \& De Luigi (2018), the incidence rate of injuries in wheelchair tennis is $12.7 \%$, in which $37 \%$ are acute injuries and $47 \%$ are caused by overuse. Caldwell \& De Luigi (2018) states that during the 1992 Paralympics, $75 \%$ of wheelchair tennis players acquired at least one injury during training or competition.

Therefore, the racket's grip is decisive to improve performance and avoid injuries during the game, and the way the racket is held influences the racket's front angle, the position in which the ball is in relation to the body, and especially the movements that occur when the impact between the ball and the racket happens (United States Professional Tennis Association, 2018). Many wheelchair tennis athletes have difficulties with the racket tightening movement (Caldwell \& De Luigi, 2018), which can be caused by different reasons, such as poliomelia, phocomelia, myopathy, muscular dystrophy or neuropathy (International Tennis Federation, 2017). The mentioned impairments prevent athletes from being able to grasp and completely close the hand to hold the racket.

Although even with the increasing sport's relevance, players still use rudimentary solutions to solve the positioning of the racket's problem, such as tying tapes and bands to bandage their hands. Those improvised and cheap solutions cause high discomfort, excessive sweating, swelling, skin disorders and require a long time for implementation (Carvalho, 2005). Accordingly, research and technological development applied to tennis are focused on commercial sporting materials, such as clothing, balls, and rackets. Consequently, the investments in solving paralympic athlete's problems are considerably low (Carvalho, 2005).

This paper reports the experience for developing a product by undergraduate students based on project-based learning (PLB) perspective during their regular classes, in which the student's team share knowledge and engage their learning throughout the project application of the innovative 
product process (Monteiro et al. 2017). The collaborative work promoted in the PBL environment facilitates the acquisition of knowledge around a complex and illstructured problem through a new product development aiming at achieving Technology Readiness Level (TRL) 2. (Straub, 2015).

Considering this, the problem is to develop an assistive device designed for quadriplegic tennis players who play in Quad modality, classified as wheelchair tennis with a hand problem. Specifically, this project aims to solve the problem of grabbing and transmitting racket's force during the game by practitioners of wheelchair tennis with incomplete quadriplegia in consonance with the product development process theory (Otto \& Wood, 2001; Dieter, 2000; Ulrich \& Eppinger, 2004).

The objective was to achieve TRL 2 through the development of an assistive technology product project using traditional product development approaches in a PBL environment. TRL 2 involves the transition between the observed and reported basic principles and a technology concept or application formulated. The traditional product development approaches were used to increase knowledge and understanding of the classical PDP within a PBL environment.

This paper is divided into 4 sections. Section 1 presents the research context and the study general objective. Section 2 presents theoretical concepts related to the PBL approach, Paralympic Tennis Quad, PDP, and TRL. Section 3 includes the methods report, section 4 discusses identified results and section 5 discusses the experience, particularities, and possibilities to the future.

\section{Literature review}

\subsection{Project-based learning approach}

The product development stated in this article is based on the PBL approach, an active learning method that became very popular within engineering education, due to its positive impact with realistic outcomes on students learning and engagement (Zancul et al., 2017). It is based on principles of adult learning theory, including motivating the students, encouraging them to set their own learning goals, and giving them a role in decisions that affect their own learning (Wood, 2003).

The PBL supports the development of engineering students by means of practical tasks given by real-life problems or the company's requirements. The PBL approaches provoke students to investigate a real-life problem that could be sorted out by means of a product or to bring a requirement of any company, with the regard to promote knowledge expansion in product development for the students rather than solve a company need.
The proposed teaching approach demonstrated efficiently to undertake two of the challenges faced by engineering undergraduate education for product development, the need to foster interprofessional educations and collaborative work, and to provide a complete interdisciplinary view of the information flow that enables ideas to be developed into real products (Zancul et al., 2017). The real constraints placed on functionalities, materials, manufacturing processes, or specific markets, provide new challenges for students, more than an internal project. Activities involve active learning from the company's experts by organizing team meetings that include staff from manufacturing and marketing in cases where the tasks are guided by the company's requirements (Shekar, 2007).

\subsection{Paralympic tennis quad}

The International Tennis Federation is the officially recognized entity with the authority to control official tennis rules worldwide. It regulates the official rules of tennis for people who do not have disabilities and for athletes who play tennis in a wheelchair, Quad, or open division within the sport in order to reduce the effect of the disability on sports performance (International Tennis Federation, 2017).

According to the International Tennis Federation (2017), athletes who wish to compete in the Quad category must meet at least one of the following requirements: (1) Reduced motor function required to perform an overloaded service; (2) Reduced motor function required to perform forehand or backhand; (3) Reduced motor function required to operate a manual wheelchair, (4) Inability to hold the racket, requiring the need to cover and/or use a support device to play.

According to Bardales (2013), the importance of gathering information from existing technologies and similar products consists of generating a consistent base of pieces of evidence about the functions of similar products and products that meet the needs of customers. The available evidence directly influences the cost estimate of the alternatives of the product under development and can include everything from product characteristics to material type properties and specifications.

Furthermore, the solutions currently applied involve rudimentary technological robustness, choosing materials such as gloves, ribbons, bows, and glues to tie the hand to the tennis racket. This lacking technological innovation is also a strong warning paving the way to develop new products, which are capable of enabling and improving the experience of tennis players, professional or not, in the Paralympic modality called "Quad" (Carvalho, 2005).

\subsection{Product development process}

The product development process consists of a set of activities that, based on market needs, technological restrictions, and strategies of the company, seek to reach the 
project specifications of a product and its production process (Rozenfeld et al., 2006). Moreover, it is a competitive strategy led by-products and environmental sustainability, which begins with the perception of a market opportunity and ends with the production, sale, and delivery of a product (Ulrich \& Eppinger, 2004).

Conversely, the product development process has several problems in the progress of theory and concepts (Shaw, 1995). Many problems in the production area derive from the lack of theoretical studies based on a systematic method (Conforto et al., 2011). Besides, Hart \& Moore (1997) highlights the relevance of investigating and understanding the knowledge broadly before starting research. Therefore, the problem definition is the starting point for the scientific review during the product development process (Conforto et al., 2011). The main phases of the product development process and the expected results of each step are illustrated in Figure 1.

According to Bardales (2013), the product development process starts with an idea or demand from the internal customer, and later the sales team starts the prospecting and survey phase with external customers and possible interested parties. Market research integrates the consumer, customer, and community with professionals through information.
It involves the processes of collecting information from different data sources, that can be divided into two main sources: primary and secondary (Rozenfeld et al., 2006).

Primary sources provide data directly available from the user, considering the project needs. Secondary sources make available information for other purposes that, although have not been acquired for the primary needs of the project, are useful. Qualitative research uses methods capable of analyzing abstract information, such as consumer concepts, for example, materializing user's perceptions. Direct observation and content analysis from transcribed speeches are types of qualitative research, in which the researchers have access to consumer's opinions directly when they are exposed by the first time to the product or its primary idea (Rozenfeld et al., 2006; Madzik et al., 2019).

After defining the problem, the following step is to define the product life cycle, that provides a graphical description of the product's stages and depends on the type of project, production scale, operating characteristics, among others. In order to define the customer requirements, analysis, and categorization of the customer needs considering each lifecycle stage are necessary, through classifications, ordering, and grouping techniques. Customers can express themselves in terms of product failures or expectations and

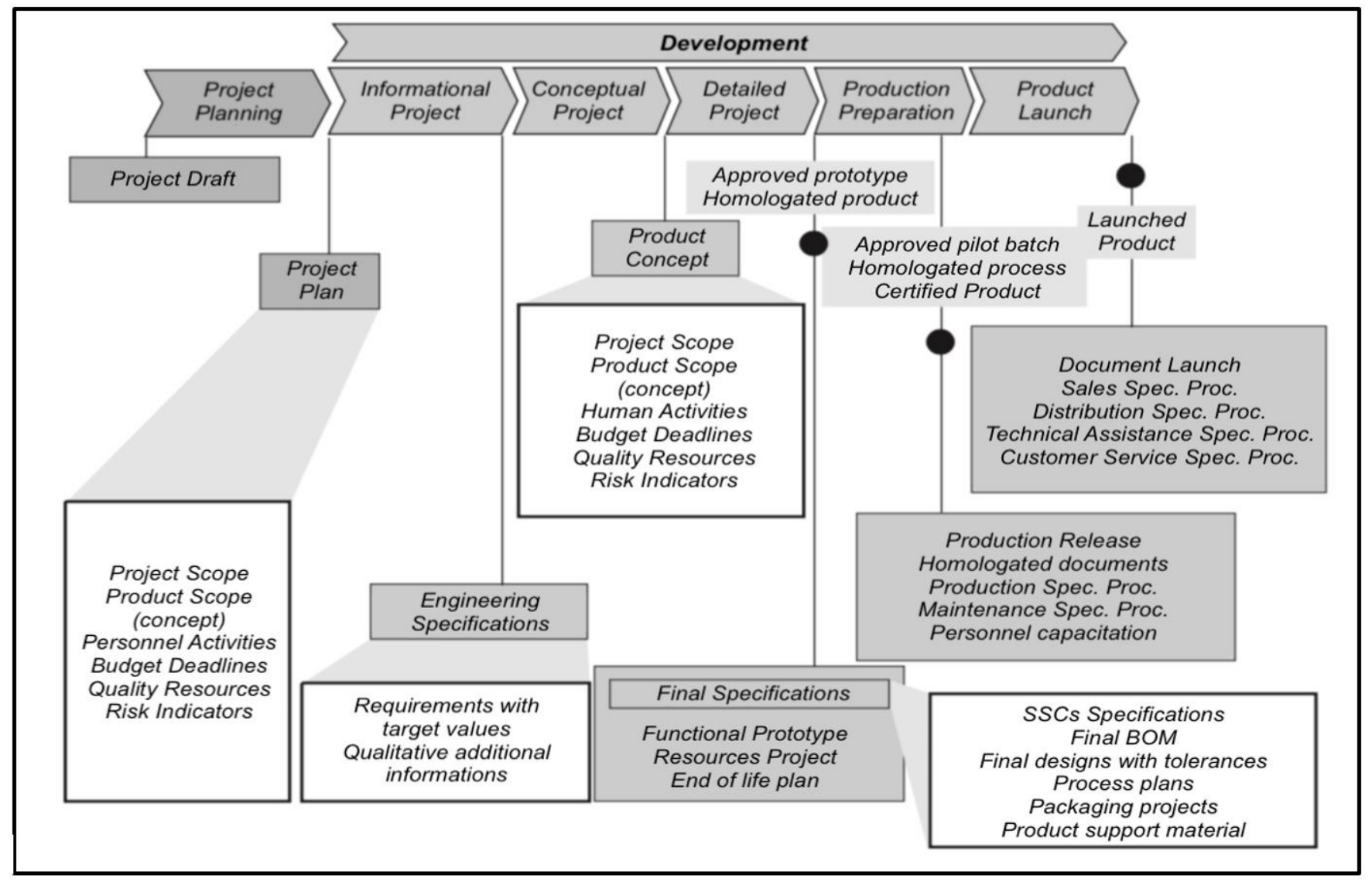

Figure 1. Product Development Process phases and deliverables. Sources: Rozenfeld et al. (2006). 
this gathering information can be represented graphically through the Kano Diagram, which considers customer satisfaction versus product performance (Kano et al., 1984; Madzik et al., 2019).

Subsequently, the product specifications are derived from the customer's requirements (Hauser \& Clausing, 1988). The informational project aims to develop the product's target specifications, through the information collected in the planning phase (Back et al., 2008).

The specifications guide design solutions and serve as a basis for assembling the evaluation and decision-making criteria used in the following PDP stages. In order to obtain accurate communication during the project, the customer requirements are translated into technical engineering language because customer needs tend to express customer's wishes in a subjective way. The conversion of product requirements into product specifications defines measurable parameters, associated with product characteristics (Akao, 1990; Kwong et al., 2007; Franceschine \& Maisone, 2015; Madzik et al., 2019).

According to Back et al. (2008) and Rozenfeld et al. (2006), unlike the informational project phase that deals with the acquisition and transformation of information, the conceptual project consists of the search, creation, representation, and selection of solutions to the problem, aiming at obtaining the product design. The conceptual design phase ideally follows a linear process but typically is realized through a highly iterative one. The design problem is elucidated, and function decomposition follows. Solutions for each sub-function are identified and combined to create a potential integrated conceptual design (Clausing, 1994; Ullmann, 1997; Ulrich \& Eppinger, 2004).

The morphological chart represents a methodology for organizing alternative solutions for each function of a product and combining them to generate solutions variants that potentially satisfy the product functional analyses. The outcome for the morphological chart is based on numerous possible concepts, derived from the combination of Solution Principles for each function identified. (Pahl et al., 2007, Mansor et al., 2014). Although, the concept generation needs to be guided by experienced designers to identify conflicting Solution Principles (Yang \& Basen, 2008; Liverani, et al., 2019).

\subsection{Technology Readiness Level}

The TRL has a long history at NASA and the American Department of Defence when designing and testing new technologies (Mankins, 1995). The method was created to assess the maturity level of new technologies developed at the agencies to predict the time and readiness to application in real case scenarios. The advent of these metrics provided a valuable tool for communication between the research and development (R\&D) departments and those involved in both ongoing and proposed projects (Hicks et al. 2009). The TRL is based on nine levels of development, with specific descriptions of each level to assess the development of projects and technologies. The nine levels are summarized in Table 1.

Although the TRL approach determines the maturity of technologies. The product development process is not linear process. The TRL system recognize the time of and degree of technical risk of technology development. Product development and advancement depend on a multitude of factors, including new and emerging technologies, as technological leadership is often a key product differentiator (Hicks et al., 2009, Salerno et al., 2015).

In order to prevent the limitations for the TRL in product development, in this article, the concept for TRL level 2, the desirable level for the proposed PBL exercise, will be the development of a concept, regarding the PDP tools, prior the analytical and laboratory experimentation for proof of concept.

\section{Methodology}

The University of Brasilia (UnB)'s Industrial Engineering undergraduate program presents an innovative curriculum, which is based on the Project Based Learning methodology (PBL). The program has been designed with a length of 12 semesters. It first began in the second half of 2009, and graduated its first group of engineers in the second semester

Table 1. Technology Readiness Level definition based on nine levels of development (Hicks et al., 2009).

\begin{tabular}{|c|l|}
\hline TRL & \multicolumn{1}{|c|}{ Definition } \\
\hline 1 & Principal research into the core properties of a technology. \\
\hline 2 & 'Invention' of a concept or application for the technology. Shift from principle to applied research. \\
\hline 3 & $\begin{array}{l}\text { Initial 'proof of concept' of critical functionality through active R\&D (Analytical and laboratory studies in appropriate context to } \\
\text { validate previous analytical predictions). }\end{array}$ \\
\hline 4 & Low-fidelity validation in laboratory environment. Technological advancement now focussed on meeting project requirements. \\
\hline 5 & Validation of basic technological elements in a relevant environment. Test 'set-up' to be of higher fidelity than at TRL 4. \\
\hline 6 & High fidelity 'alpha' prototype demonstrated in a relevant environment. \\
\hline 7 & 'Beta' prototype demonstrated in an operational environment. \\
\hline 8 & Completed component, sub-system or system qualified to relevant project requirements and/or regulatory standards. \\
\hline 9 & Certified component, sub-system or system proven to meet all project requirements through 'real world' operation. \\
\hline
\end{tabular}


of 2014. The program features eight courses labeled Production Systems Projects (PSP), all of which apply the PBL approach, and are held from the 3 rd to the 5 th year of the program (Monteiro et al., 2017).

This paper reports the experience for developing a product by undergraduate students based on project-based learning (PLB) perspective during their regular classes, in which the student's team share knowledge and engage their learning throughout the project.

According University of Brasilia (UnB)'s Industrial Engineering undergraduate program in course of Production Systems Design 6 (PSP6) are knowledge explored about the Product Development Process. This course is an interdisciplinary with greater technical complexity than compared to others of the same nature in curriculum of program.

In the first class, the problems are presented by external agents and then teams are formed. This paper presents the evolution of a team that worked with development of a device for reintegration of people with incomplete quadriplegia.

The external agent was the Centro de Treinamento Educação Física Especial (CEFETE) which is a nonprofit organization that provides free services to people with some type of physical disability. A tennis instructor, a physiotherapist, five athletes and two teachers were involved in the design process.

The process to develop of the new device based on the PDPnet, focusing on 4 main steps: (1) Data collection on customer needs; (2) Conversion of customers' requirements into product specifications; (3) Morphological chart and solution principles and (4) Design of the first prototype.

The study object is the use of the PDPnet process reference model developed by Rozenfeld et al. (2006) for the project of a product that allows reintegration of people with incomplete quadriplegia in a specific sport, using data to translate the user needs to user requirements, product requirements, solution principles, and a prototype aiming to achieve TRL 2. The overall step by step of the project structure of the product development is represented in Figure 2. The steps 1 to 4 were described in this article.

As listed, the first step was the data collection on customer needs. At this stage, primary and secondary sources, as well as direct observations were applied to collect human perception. With reliable techniques of data collection, we classified user needs translating into customer requirements, concerning the lifecycle phases. The second step was to convert customer requirements into product specifications. An evaluation of customer satisfaction and product performance through a Kano Diagram allowed us to highlight the customer requirement's prioritization. This stage was crucial to define the first definition of critical product parameters.

In order to establish valuable product specifications, a functional analysis was performed in the third step. This is based on the main function the product needs to execute and the logical steps to achieve it. Therefore, the logical steps are translated into basic functions, following a hierarchical relationship each time a function needs to be decomposed in two or more. Afterward, we applied the Morphological chart to generate alternative solutions and three concepts were generated using combinations for the solution principles proposed at the Morphological chart.

The evaluation of the best concept was performed according to a compliance degree with the product requirements. With the definition of a concept, a prototype was proposed in the fourth step. In order to design the prototype, we created CAD (Computer-Aided Design) models. The concept was adapted to make possible the use of shelf products, such as locking systems and wearables. The concept was manufactured using FDM printers and the final assembly was performed by the university team.

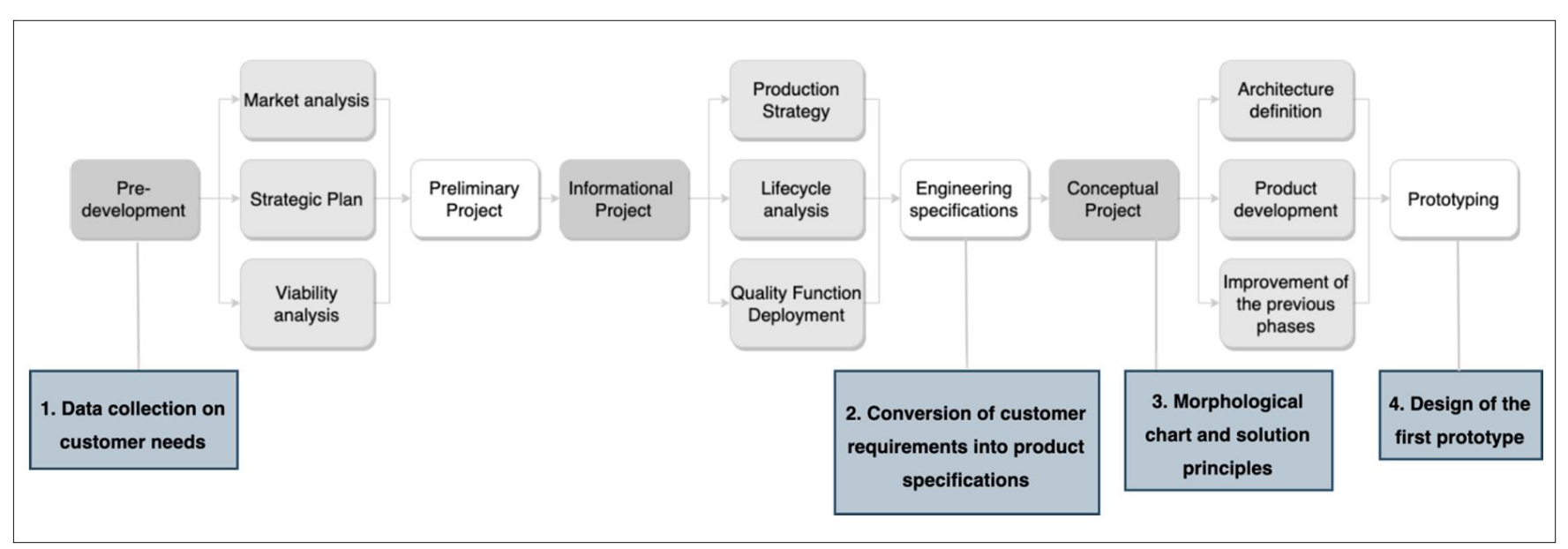

Figure 2. Project structure adopted for this study. Sources: the authors (2019) 


\section{Results}

\subsection{Data collection on customer needs (user-centered approach)}

To identify the customer needs, three main techniques were used for data collection: (a) survey of primary sources, which consists of conducting interviews with those responsible for Training Center and Paralympic athletes, (b) survey of secondary sources, which includes scientific researches and methods to assist in the study, and (c) direct observation, which consists of technical visits to the site to assist in the product project.

The main objective of the survey of primary sources was to specifically identify the customers and list the involved problems of tennis players with disabilities. A questionnaire was designed, considering the player's problems and complications, difficulties, and undesirable outcomes faced during the game. A survey through questionnairebased interviews with members of the Training Center and Paralympic athletes was followed by a documental analysis and reports from the training programs and games. We identified that the players continuously use ribbons to grab the racket and this causes allergies, circulation problems, discomfort during the game, loss of time while attaching the hand, and loss of money to buy disposable ribbons. The use of ribbons caused injuries in many players, affecting the wrist, shoulder, and elbow movements and amplifying several diseases or physical disabilities such as multiple and lateral sclerosis, polio, atrophy, dystrophy, brachial plexus injury, peripheral nerve injury, among others.

The general purpose of the survey of secondary sources was to measure how the target customers feel towards a new product that helps to grab the tennis racket. A market research questionnaire was designed and a survey was conducted with Brazilian Quad players. In 2018, 313 players were classified in the Olympic Quad category. Of these, the country with the most participants in Japan with $18 \%$, followed by the United States with 15\%. Moreover, 274 of the 313 players who reported their year of birth, $57 \%$ were born between the $60 \mathrm{~s}$ and $70 \mathrm{~s}$. Therefore, the majority of the public practicing this sport is between 39 and 58 years old. Another factor found was that $90 \%$ of athletes are male. Brazil had a total of 8 players registered in 2018. In 2015, 257 players were classified in this category, with a total of 4 Brazilian players.

We verified that $80 \%$ of the Brazilian players have reduced strength in their hands or $\mathrm{C} 6 / \mathrm{C} 7$ spinal cord injuries or difficulty holding the racket throughout the game, but they believe that the tennis practice helps to deal with the disability. Besides, the disability affects the racket backhand movement, maintaining the racket at impact with the ball, positioning the racket, making the movement with both hands, and holding the racket. Moreover, $75 \%$ of the Brazilian players use adaptations such as Durex, tapes, ribbons, or adhesives during the game or training. The direct observations consisted of technical visits to the site, observation of videos in conventional tournament games, and Paralympic tennis.

The collected data was divided into bibliographic, documentary, and statistical data and classified as macro necessities within each stage of the product life cycle. An analysis of the product lifecycle at this stage was important to maximize the value of the customer's needs (Stark, 2015; Zhang et al., 2017). The stakeholder analysis and activities deployment within each lifecycle main activity provided a view of the main approach: assemble to order, in which final products are assembled only after customer orders are made. Despite the commonly known problem with component commonality, the degree of modularity, postponement and substitution were considerably high.

The macro necessities were grouped into the attribute's operation, ergonomics, aesthetics, economical, normalization, and modular. The categorized macro necessities were subdivided into primary necessities, identified its scenarios, and mapped into customer requirements. Table 2 shows the breakdown of macro necessities identified with the collected data into customer requirements. The necessities correspond to one, two, or three customer requirements and the scenario's correlation was fundamental to define and categorize main terms identified on customer needs. These requirements were analyzed regarding its necessities and impact through a Kano diagram.

\subsection{Conversion of customer requirements into product specifications}

One of the main purposes of the Kano diagram (Figure 3) was to connect the requirements fulfilled with customer satisfaction and identify three ultimate influences: must-be, one-dimensional, and attractive. The Kano diagram showed of that requirements number 4B, 6A, 7B, 9A, 10A, 11B, $12 \mathrm{~A}, 12 \mathrm{~B}$, and $15 \mathrm{~A}$ leads to greater satisfaction, whereas it is not expected to be in the product. The fulfillment of attributes number $2 \mathrm{~A}, 2 \mathrm{C}, 3 \mathrm{~A}, 6 \mathrm{~B}, 14 \mathrm{~B}$, and $16 \mathrm{~A}$ helps to increase satisfaction and vice-versa. Absence of attributes number $1 \mathrm{~A}, 1 \mathrm{~B}, 1 \mathrm{C}, 2 \mathrm{~B}, 4 \mathrm{~A}, 5 \mathrm{~A}, 6 \mathrm{C}, 7 \mathrm{~A}, 7 \mathrm{C}, 11 \mathrm{~A}, 12 \mathrm{C}$, $13 \mathrm{~A}$, and $14 \mathrm{~A}$ produces absolute dissatisfaction and its presence does not increase satisfaction. Besides, to this classification, must-be attributes should be kept, onedimensional and attractive attributes should be added, and neutral attributes should be avoided (Harijith \& Naduthodi, 2017; Sharif Ullah \& Tamaki, 2011).

The Kano diagram showed the need to find new requirements that impact customers, but these requirements are generally still in the form of needs, without being 
Table 2. Breakdown of the macro necessities into customer requirements.

\begin{tabular}{|c|c|c|c|c|c|}
\hline Macro Necessities & Primary Necessities & Scenario & $\begin{array}{c}\text { Customer } \\
\text { Requirements (A) }\end{array}$ & $\begin{array}{c}\text { Customer } \\
\text { Requirements (B) }\end{array}$ & $\begin{array}{c}\text { Customer } \\
\text { requirements }(\mathrm{C})\end{array}$ \\
\hline \multirow{4}{*}{ Needs of use } & 1. Be functional & $\begin{array}{l}\text { Product solves the } \\
\text { customer problem }\end{array}$ & $\begin{array}{l}\text { 1.A Secure locking to } \\
\text { players hand }\end{array}$ & $\begin{array}{l}\text { 1.B Allows } \\
\text { transmission of power } \\
\text { to the racket }\end{array}$ & $\begin{array}{l}\text { 1.C Secure locking to } \\
\text { the racket }\end{array}$ \\
\hline & 2. Don't hurt & $\begin{array}{l}\text { Safe product and } \\
\text { no health risk to the } \\
\text { athlete }\end{array}$ & 2.A Lightweight & $\begin{array}{l}\text { 2.B Allows free blood } \\
\text { circulation }\end{array}$ & $\begin{array}{l}\text { 2.C Possess } \\
\text { comfortable materials }\end{array}$ \\
\hline & $\begin{array}{l}\text { 3. Easy to prepare } \\
\text { the use }\end{array}$ & $\begin{array}{l}\text { Low time to prepare } \\
\text { the use }\end{array}$ & $\begin{array}{l}\text { 3.A Easy to assemble } \\
\text { and disassemble }\end{array}$ & & \\
\hline & $\begin{array}{l}\text { 4. Possibility to store } \\
\text { the product after use }\end{array}$ & $\begin{array}{l}\text { Product can be stored } \\
\text { without difficulties }\end{array}$ & 4.A Easy to clean & 4. $\mathrm{B}$ Be reusable & \\
\hline $\begin{array}{l}\text { Respect to } \\
\text { the customer } \\
\text { protection laws }\end{array}$ & $\begin{array}{l}\text { 5. Adherence to the } \\
\text { codes, statutes and } \\
\text { defense bodies }\end{array}$ & & $\begin{array}{l}\text { 5.A Contain } \\
\text { recommendations } \\
\text { and side effects for } \\
\text { product use }\end{array}$ & & \\
\hline $\begin{array}{l}\text { Accordance with } \\
\text { physiological } \\
\text { needs of different } \\
\text { users }\end{array}$ & $\begin{array}{l}\text { 6. Contain } \\
\text { components in } \\
\text { compliance with } \\
\text { different profiles of } \\
\text { special needs }\end{array}$ & $\begin{array}{l}\text { Different injuries } \\
\text { and problems may be } \\
\text { served by the same } \\
\text { product }\end{array}$ & 6.A Be adaptable & 6.B Easy to use & $\begin{array}{l}\text { 6.C Have a format } \\
\text { that does not bring } \\
\text { risks to user health }\end{array}$ \\
\hline $\begin{array}{l}\text { Accordance with } \\
\text { basic physiology } \\
\text { of the user }\end{array}$ & $\begin{array}{l}\text { 7. Consider folds } \\
\text { anatomy, hand bows } \\
\text { and three points of } \\
\text { hand, fist and forearm } \\
\text { pressure }\end{array}$ & $\begin{array}{l}\text { Ergonomic product } \\
\text { developed for human } \\
\text { use }\end{array}$ & $\begin{array}{l}\text { 7.A Be adjustable to } \\
\text { user needs }\end{array}$ & $\begin{array}{l}\text { 7.B Contain only } \\
\text { curved and rounded } \\
\text { corners }\end{array}$ & $\begin{array}{l}\text { 7.C Free of sharp } \\
\text { corners }\end{array}$ \\
\hline Effective storage & $\begin{array}{l}\text { 8. Don't easily } \\
\text { damage }\end{array}$ & $\begin{array}{l}\text { Easy and secure } \\
\text { product to be stored } \\
\text { in large scale }\end{array}$ & $\begin{array}{l}\text { 8.A Support humidity } \\
\text { and temperature use } \\
\text { conditions }\end{array}$ & $\begin{array}{l}\text { 8.B Have drop } \\
\text { resistance packaging }\end{array}$ & \\
\hline \multirow{2}{*}{$\begin{array}{l}\text { Accessible } \\
\text { maintenance }\end{array}$} & 9. Cheap maintenance & $\begin{array}{l}\text { Cheap and accessible } \\
\text { product }\end{array}$ & $\begin{array}{l}\text { 9.A Easy to } \\
\text { disassemble } \\
\text { components } \\
\end{array}$ & & \\
\hline & $\begin{array}{l}10 . \text { User security in } \\
\text { case of product defect }\end{array}$ & $\begin{array}{l}\text { Secure product with } \\
\text { maintenance support }\end{array}$ & $\begin{array}{l}\text { 10.A Contain after } \\
\text { sales information }\end{array}$ & & \\
\hline Disposal & $\begin{array}{l}\text { 11. Easy disposal and } \\
\text { high durability }\end{array}$ & $\begin{array}{l}\text { Durable product with } \\
\text { easy disposal }\end{array}$ & $\begin{array}{l}\text { 11.A Last for } \\
\text { expected life time }\end{array}$ & $\begin{array}{l}\text { 11.B Be adaptable to } \\
\text { other uses }\end{array}$ & $\begin{array}{l}\text { 11.C Contain } \\
\text { information for } \\
\text { sustainable discard } \\
\end{array}$ \\
\hline Aesthetic & $\begin{array}{l}\text { 12. Pleasant color but } \\
\text { not flashy }\end{array}$ & $\begin{array}{l}\text { Athletes don't worry } \\
\text { too much with the } \\
\text { product aesthetic }\end{array}$ & $\begin{array}{l}\text { 12.A Have a nice } \\
\text { visual aspect }\end{array}$ & $\begin{array}{l}\text { 12.B Contain color } \\
\text { variety }\end{array}$ & $\begin{array}{l}\text { 12.C Small package } \\
\text { size }\end{array}$ \\
\hline $\begin{array}{l}\text { Accordance } \\
\text { with the quality } \\
\text { standard }\end{array}$ & $\begin{array}{l}\text { 13. Guarantee full } \\
\text { functioning in } \\
\text { compliance with } \\
\text { quality standards }\end{array}$ & $\begin{array}{l}\text { Product has } \\
\text { compliance } \\
\text { with technical } \\
\text { specifications and its } \\
\text { purpose }\end{array}$ & $\begin{array}{l}\text { 13.A Size restrictions } \\
\text { according to hand/ } \\
\text { arm devices }\end{array}$ & & \\
\hline Assembly & 14. Simple assembly & $\begin{array}{l}\text { Product contain a } \\
\text { manual with detailed } \\
\text { information about } \\
\text { how to assemble } \\
\text { components }\end{array}$ & $\begin{array}{l}\text { 14.A Secure locking } \\
\text { of components to } \\
\text { main module }\end{array}$ & $\begin{array}{l}\text { 14.B Be intuitive } \\
\text { and didactic for } \\
\text { components assemble }\end{array}$ & \\
\hline \multirow{2}{*}{$\begin{array}{l}\text { Reliable } \\
\text { transportation }\end{array}$} & 15. Easy to transport & $\begin{array}{l}\text { Product easy to carry } \\
\text { and transport }\end{array}$ & $\begin{array}{l}\text { 15.A Easy to carry } \\
\text { package }\end{array}$ & $\begin{array}{l}\text { 15.B Contain only } \\
\text { one packaging } \\
\text { volume }\end{array}$ & \\
\hline & $\begin{array}{l}\text { 16. Secure quality } \\
\text { and integrity of } \\
\text { the product during } \\
\text { transport }\end{array}$ & $\begin{array}{l}\text { Certified transport } \\
\text { with low incidence of } \\
\text { problems }\end{array}$ & $\begin{array}{l}\text { 16.A Be impact and } \\
\text { risks free }\end{array}$ & & \\
\hline
\end{tabular}




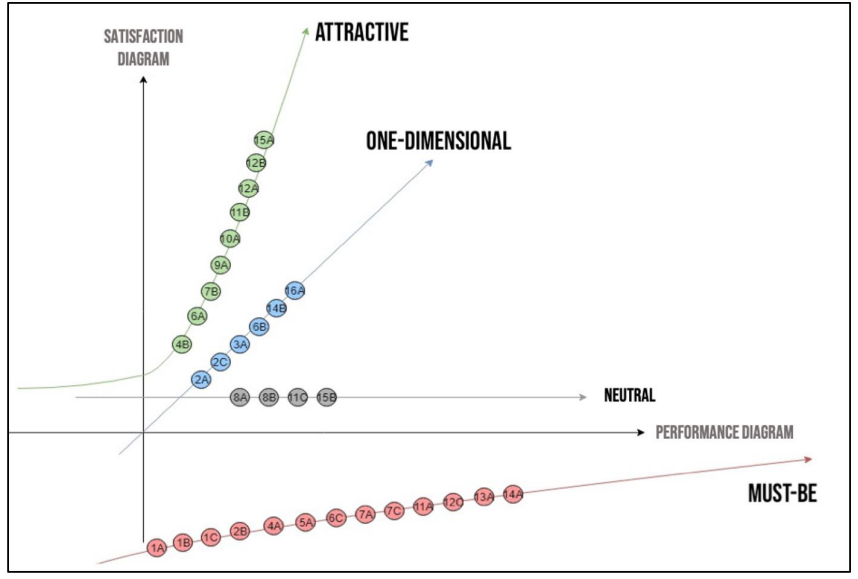

Figure 3. Kano Diagram. Source: The authors (2019) associated with measurable characteristics. To obtain accurate communication during the development, the technical language of engineering must be in accordance with the information that characterizes the product. This stage of conversion of customer requirements into product specification, which can be observed in Table 3, was the first physical decision about the product. Most of the customer requirements were translated into only one product requirement (in Table 3) with the exception of the comfort of the device, which can be seen as the balance between tensile strength and elasticity module of the materials used.

Most of the main concerns of the customers were related with the time and ease to assemble and disassemble the device, given that one of the most used solutions (taping

Table 3. Customer requirements and converted product specifications.

\begin{tabular}{|c|c|c|c|}
\hline ID & Customer Requirements & Product Specifications (A) & $\begin{array}{c}\text { Product } \\
\text { Specifications (B) } \\
\end{array}$ \\
\hline 1.A & Secure locking to players hand & Locking force $[\mathrm{N}](+)$ & \\
\hline $1 . \mathrm{B}$ & Allows transmission of power to the racket & Tensile Strength [MPa] $(+)$ & \\
\hline $1 . \mathrm{C}$ & Secure locking to racket & Locking force $[\mathrm{N}](+)$ & \\
\hline 2.A & Lightweight & Weight $[\mathrm{Kg}](-)$ & \\
\hline $2 . \mathrm{B}$ & Allows free blood circulation & Hand compression $[\mathrm{Pa}]$ - & \\
\hline 2.C & Possess comfortable materials & Tensile Strength $[\mathrm{MPa}](+)$ & $\begin{array}{l}\text { Mo d u l u s of } \\
\text { Elasticity }[\mathrm{MPa}](-)\end{array}$ \\
\hline 3.A & Easy to assemble and disassemble & Time to couple components together (s) (-) & \\
\hline 4.A & Easy to clean & Washing time $(\mathrm{s})(-)$ & \\
\hline 4.B & Be reusable & Lifetime (cycles) & \\
\hline 5.A & $\begin{array}{l}\text { Contain recommendations and side effects for product } \\
\text { use }\end{array}$ & Recommendation quantity/ Contraindications $(\mathrm{n})(+/-)$ & \\
\hline 6.A & Be adaptable & Number of possible global functions $(\mathrm{n})(+)$ & \\
\hline $6 . \mathrm{B}$ & Easy to use & Time to prepare $(\mathrm{t})(-)$ & \\
\hline $6 . \mathrm{C}$ & Have a format that does not bring risks to user health & Length of material $(\mathrm{cm})(-)$ & \\
\hline 7.A & Be adjustable to user needs & Number of adjustments (n) $(+)$ & \\
\hline 7.B & Contain only curved and rounded corners & $\%$ of rounded corners. $(\%)(-)$ & \\
\hline 7.C & Free of sharp corners & Quantity of sharp corners (n) (-) & \\
\hline 8.A & Support humidity and temperature use conditions & $\begin{array}{l}\text { Resistance to corrosion (\% of stainless components) } \\
(+)\end{array}$ & \\
\hline $8 . \mathrm{B}$ & Have drop resistance packaging & Tenacity $(\mathrm{J})(+)$ & \\
\hline 9.A & Easy to disassemble components & Time to disassemble (t) (-) & \\
\hline 10.A & Contain after sales information & Quantity of maintenance recommendations (n) (+/-) & \\
\hline 11.A & Last for expected life time & Life time $(\mathrm{T})(+)$ & \\
\hline 11.B & Be adaptable to other uses & Number of possible global functions (n) $(+)$ & \\
\hline 11.C & Contain information for sustainable discard & Quantity of recycling recommendations $(\mathrm{n})(+)$ & \\
\hline 12.A & Have a nice visual aspect & $\begin{array}{l}\text { Percentage of visual aesthetics acception((Number of } \\
\text { acception/total }) * 100))(+)\end{array}$ & \\
\hline 12.B & Contain color variety & Number of possible colors (n) (-) & \\
\hline 12.C & Small package size & Volume of device $(\mathrm{cm} 3)(-)$ & \\
\hline 13.A & Size restrictions according to hand/arm devices & Diameter $(\mathrm{cm})(+/-)$ & \\
\hline 14.A & Secure locking of components to main module & Components precision $(\mathrm{mm})(-)$ & \\
\hline 14.B & Be intuitive and didactic for components assemble & Time to assemble(t) (-) & \\
\hline 15.A & Easy to carry package & $\begin{array}{l}\text { Quantity of components that facilitate transportation } \\
\text { (n) }(+/-)\end{array}$ & \\
\hline 15.B & Contain only one packaging volume & Number of packages in each delivery (n) (-) & \\
\hline 16.A & Be impact and risks free & Materials Elasticity (E(Youngs Module) (+/-) & \\
\hline
\end{tabular}


the hand to the racket) was reported as was reported as time demanding and if it was done in a wrong way, would be time-consuming to reassemble. This generated some product specifications that were measured with time such as time to prepare, couple components, assemble, and disassemble. Another important concern of the users was the solution should be comfortable, which can hurt the player's hands in prolonged use. This calls to the importance of the material that will be used for the device. A balance between strength, so that the players have a firm grip on the racket and elasticity so that the material isn't too hard on the hand and arms are observed on the product specifications.

\subsection{Morphological chart and solution principles}

Based on the scenario of use an analysis of functionalities was executed. This analysis helps to understand the functions that the product needs to perform and to start developing solution principles (SP) for each task that the product needs to achieve.

The functional analysis developed by the university team designated a main function for the product, to increase the handgrip for a tennis racket. In order to perform its global function, seven basic functions were mapped, as presented in the functional analyses illustrated in Figure 4. Subsequently, SP's were proposed for each basic function, developing a morphological chart, presented in Table 4.

The morphological chart presents structured paths to define product architecture. To achieve a final design for the product three concepts were chosen from the options denoted in the morphological chart. The three concepts are illustrated in Figure 5. To evaluate the concepts, a matrix correlating each concept to the product requirements was developed. The best concept was selected through a sum of scores for each requirement compliance degree. As a rule, to denote each score, concept 1 was selected as a pattern and all his scores were considered 0 , for the remaining concepts a score of +1 or -1 was derived through comparison. The final scores were 0 for concept $1,+1$ for concept 2 , and -1 for the third concept. Consequently, the selected concept was concept 2.

\subsection{Design of the first prototype}

In order to obtain a better understanding of the chosen concept and its respective functions, a rapid prototype was proposed. The module designed to hold the racket was

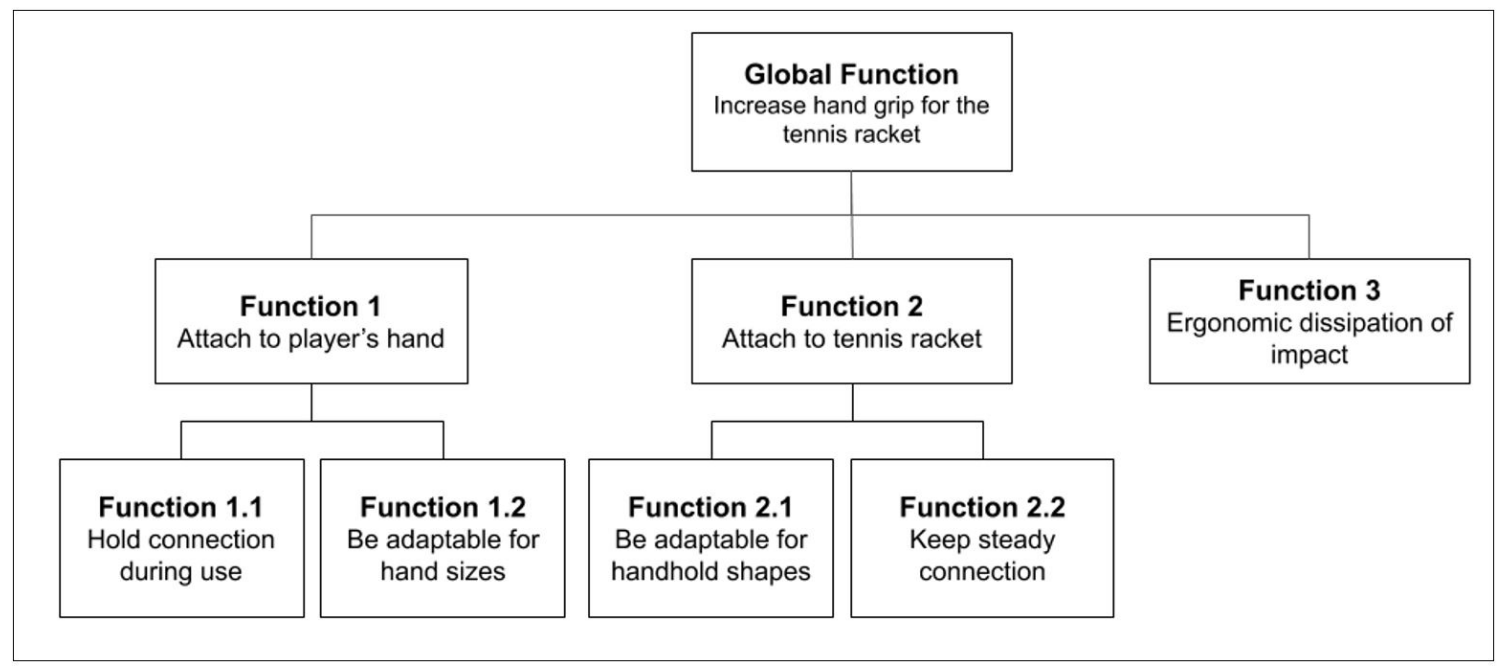

Figure 4. Functional Analyses including global function and seven basic functions. Source: The authors (2019)

Table 4. Morphological Chart based on seven basic functions.

\begin{tabular}{|c|c|c|c|c|c|}
\hline ID & Function & Solution principle 1 & Solution principle 2 & Solution principle 3 & Solution principle 4 \\
\hline 1 & Attach to player's hand & Tape & Glove & Rope/wrap & Arm connection \\
\hline 2 & Attach to tennis racket & $\begin{array}{l}\text { Lock for fingers } \\
\text { positions }\end{array}$ & Magnetic connection & Squeezing feature & Snap fit \\
\hline 3 & Ergonomic dissipation of impact & Ergonomic design & Absorptive material & Uncoupled modules & \\
\hline 1.1 & Hold connection during use & Locking Tissue & Glue & Tape & Mechanical lock \\
\hline 1.2 & Be adaptable for hand sizes & Flexible characteristic & Locking Tissue & Adjustable wraps & $\begin{array}{c}\text { Interchangeable } \\
\text { components }\end{array}$ \\
\hline 2.1 & Be adaptable for handhold shapes & Flexible characteristic & $\begin{array}{c}\text { Interchangeable } \\
\text { components }\end{array}$ & Adjustable wraps & \\
\hline 2.2 & Keep steady connection & Locking Tissue & Glue & Tape & Mechanical lock \\
\hline
\end{tabular}


modeled using CAD software, presented in Figure 6. The numbered features represent solutions for adaptability (1), easy and fast locking and releasing $(2)$, comfort $(3,5)$, and reduction of stress over hands and wrist (4). To manufacture the module designated to hold the racket the Fused Filament Fabrication (FFF) process was selected. The FFF is a consolidated manufacturing process for fast prototyping, for that reason, it was selected to fabricate it. To simulate the hand bandage a hand-split was adapted to the product, using a locking tissue to wrap the component and secure locking during tests and analyses. To perform the locking feature for the racket to the structure, a fast locking system for bicycle seats was adapted to the prototype. The prototype is present in Figure 6.

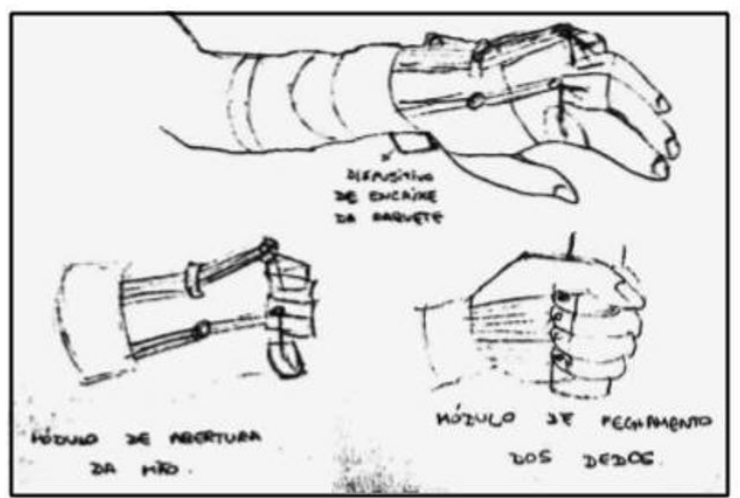

(1)

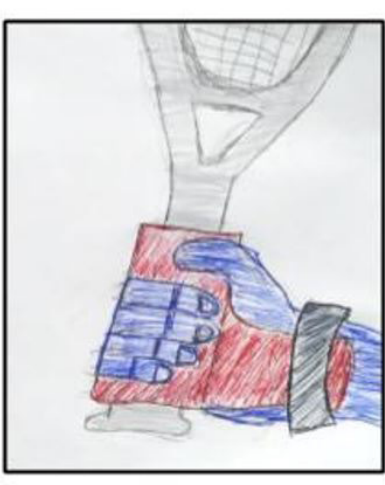

(2)

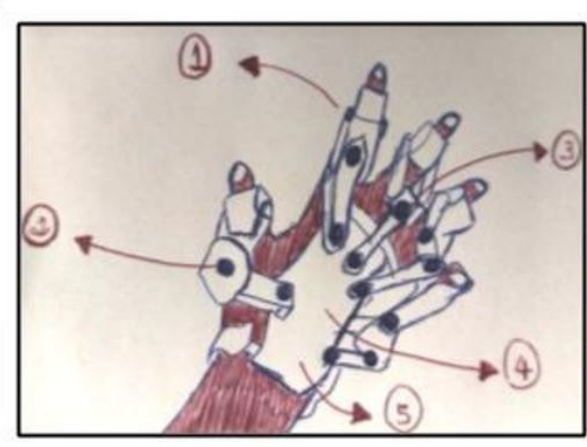

(3)

Figure 5. Proposed concepts. Source: The authors (2019).

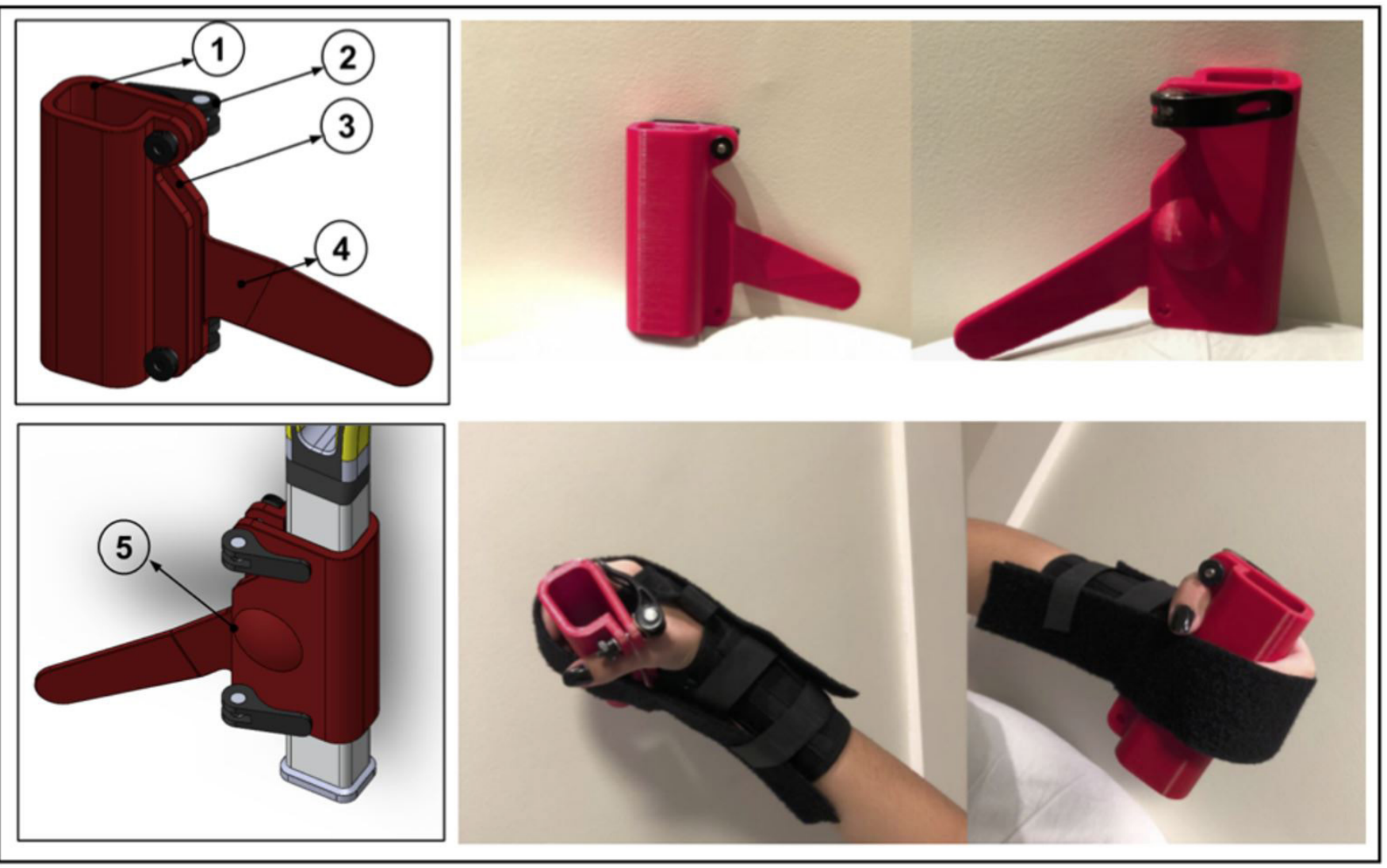

Figure 6. CAD modelling for selected concept and first product prototype. Source: The authors (2019). 
The evaluation of the manufactured prototype was executed only by user experience, this evaluation was performed by the development team and members of the Training Center. The analyses depended on the experience for comfort, the sensation of grip, and impact evaluation. The decomposition of loads with the forearm presented a consistent reduction of the stress over the wrist. The attachment to the racket and the hand were possible to be made by the user. The features to improve the sensation of grappling and the rounded corners made the use comfortable and with a safe feeling.

\section{Conclusion}

Regarding the PBL deliverables, the desired TRL was achieved with the concept definition to be proved. As stated by Hicks et al.(2009), a TRL 2 level project must present an 'Invention' of a concept or application for the technology. The prototype validation obtained through interviews with members of the Training Center demonstrates appropriate technical basic characteristics, ergonomic quality, and conformity with the theoretical framework used in its construction. The prototype presented a modular design and portability, promoting safety and functional accessibility for quadriplegic tennis practitioners.

Therefore, the study identified that despite the restricted market, the solutions currently applied are rudimentary and compromises the participation, motivation, and sporting athletes' evolution. It was observed that the prototype, besides helping racket support, potentially promotes upper limb protection, one of the main injury causes also in non-disabled athletes. Besides, it was identified that users' anthropometric characteristics, level of quadriplegia, and specific sport regiments must be considered for the product project. Interviews indicated explicit and implicit player's needs and the questionnaires applied proved to be effective in identifying musculoskeletal obstacles related to pain.

The product development achieved the technology readiness level (TRL) 2 in the inventive step and has a high level of objectivity and reproducibility, allowing the concept use in future works. Considering this context, it can be analyzed that the research presented technical information and practical configurations in the product project, enabling the reintegration of people with incomplete quadriplegia in Quad tennis modality. To continue the research the next steps are related to analytical and laboratory studies, to confirm if the concept is viable and ready to proceed further throughout the development process.

\section{References}

Akao, Y. (1990) Quality function deployment: integrating customer requirements into product design. Cambridge, MA: Product Press.
Alden, C., \& Aran, A. (2016). Foreign policy analysis: new approaches. New York: Taylor \& Francis.

Back, N., Ogliari, A., Dias, A. \& Silva, J. C. (2008) Projeto Integrado de Produtos: planejamento, concepção e modelagem. Barueri, SP: Manole.

Bardales, A. M. (2013). Modelo de estimativa de custos para as fases iniciais do projeto de produto mecatrônico [Master's Thesis], Universidade de Brasília, Brasília.

Caldwell, M., \& De Luigi, A. J. (2018). Wheelchair Dance Sport. In A. J. De Luigi. Adaptive sports medicine (pp. 171-179). Cham: Springer.

Carvalho, A. A. S. (2005). Miopatias. Revista Neurociências, 13, 35-38.

Clausing, D. (1994). Total quality development. New York: ASME Press.

Conforto, E. C., Amaral, D. C., \& Silva, S. D. (2011). Roteiro para revisão bibliográfica sistemática: aplicação no desenvolvimento de produtos e gerenciamento de projetos. In $8^{\circ}$ Congresso Brasileiro de Gestão de Desenvolvimento de Produto - CBGDP (pp. 1-12). Porto Alegre.

Dieter, G. E. (2000). Engineering design: materials and processing approach. Boston: McGraw-Hill.

Franceschine, F., \& Maisone, D. (2015). Prioritization of QFD customer requirements based law comparative judgments. Quality Engineering, 27, 437-449.

Harijith, R., \& Naduthodi, H. (2017). Kano model customer satisfaction analysis of medical services. International Research Journal of Engineering and Technology, 4(6), 1426-1429.

Hart, O., \& Moore, J. (1997). Default and renegotiation: A dynamic model of debt. The Quarterly Journal of Economics, 113, 1-41.

Hauser, J. R., \& Clausing, D. (1988). The House of Quality. Harvard Business Review, 66(3),63-73.

Hicks, B., Larsson, A., Culley, S., \& Larsson, T. (2009). A methodology for evaluating technology readiness during product development. In 17th International Conference on Engineering Design (ICED'09) Design has never been this $\mathrm{cool}$, Stanford University, California, USA. Design Society.

International Tennis Federation - ITF. (2017). Quad Draw Player List, 2017. Retrieved in YEAR, MONTH DAY Consut. 2018-08-28, from https://www.itftennis.com/en/

Kano, N., Seraku, N., Takahashi, F., \& Tsuji, S. (1984). Attractive quality and must-be quality. Journal of Japanese Society for Quality Control, 14, 39-48.

Kwong, C. K., Chen, Y. Bai, H., \& Chan, D. S. K. (2007). A methodology of determining aggregated importance of 
engineering characteristic in QFD. Computers \& Industrial Engineering, 53, 667-679.

Liverani, A., Caligiana, G., Frizziero, L., Francia, D., Donnici, G., \& Dhaimini, K. (2019). Design For Six Sigma (DFSS) for additive manufacturing applied to an innovative multifunctional. International Journal of Interative Design and Manufacturing, 13, 309-330.

Madzik, P., Lisa, L., \& Budaj, J. (2019). Determining the importance of customer requirements in QFD - a new approach based on Kano Model its comparation with other methods. Quality-Acess To Success., 20, 3-15.

Mankins, J. C. (1995). Technology Readiness Levels. A White Paper. April 6. Washington, DC, USA: Advanced Concepts Office, Office of Space Access and Technology, NASA. Retrieved in YEAR, MONTH DAY Consut. 201811-06, from http://www.artemisinnovation.com/images/ TRL_White_Paper_2004-Edited.pdf

Mansor, M. R., Sapuan, S. M., Zainudin, E. S., Nuraini, A. A., \& Hambalic, A. (2014). Conceptual design of kenaf fiber polymer composite automotive parking brake lever using integrated TRIZ-Morphological Chart-Analytic Hierarchy Process method. Materials \& Design, 54, 473-482.

Monteiro, S. et al. (2017). A Project-based Learning curricular approach in a Production Engineering Program. Production, 27, 1-12.

Otto, K., \& Wood, K. (2001) Product design: techniques in reverse engineering and new product development. New York, Prentice Hall, 2001.

Pahl, G., Beitz, W., Feldhusen, J., \& Grote, K. H. (2007). Engineering Design: A systematic approach (3rd ed.). London: Springer-Verlag.

Rozenfeld, H., Forcellini, F. A., Amaral, D. C., Toledo, J. C., Silva, S. L., Alliprandini, D. H. \& Scalice, R. K. (2006). Gestão do desenvolvimento de produtos: Uma referência para a melhoria do processo. São Paulo: Saraiva.
Salerno, M. S., Gomes, L. A. V., Silva, D. O., Bagno, R. B., Freitas, S. L. T. U. (2015). Innovation processes: which process for which project? Technovation, 35, 59-70.

Sharif Ullah, A. M. M., \& Tamaki, J. I. (2011). Analysis of Kano-model-based customer needs for product development. Systems Engineering, 14, 154-172.

Shaw, J. (1995). A schema approach to the formal literature review in engineering theses. System, 23(3), 325-335.

Shekar, A. (2007). Active learning and reflection in product development engineering education. European Journal of Engineering Education, 32(2), 125-133.

Stark, J. (2015). Product lifecycle management. In Product lifecycle management (Vol. 1, pp. 1-29). Cham: Springer.

Straub, J. (2015). In search of technology readiness level (TRL) 10. Aerospace Science and Technology, 46, 312-320.

Ullmann, D. G. (1997). The mechanical Design Process (2nd ed.). New York: McGraw-Hill.

Ulrich, K. T., \& Eppinger, S. D. (2004). Product design and development. New York: McGraw-Hill.

United States Professional Tennis Association - USPTA. (2018). Do You Want To Be a Player. Lake Nona, Florida.: Tennis Equipment Tips.

Wood, D. F. (2003). Problem based learning. BMJ (Clinical Research Ed.), 326, 328-330.

Yang, K., \& Basen, S. E. H. (2008). Design for six sigma: A road map for product development. New York: McGraw Hill.

Zancul, E. D. S., Sousa-Zomer, T. T., \& Cauchick-Miguel, P. A. (2017). Project-based learning approach: Improvements of an undergraduate course in new product development. Production, 27, 1-14.

Zhang, Y., Ren, S., Liu, Y., Sakao, T., \& Huisingh, D. (2017). A framework for Big Data driven product lifecycle management. Journal of Cleaner Production, 159, 229-240. 